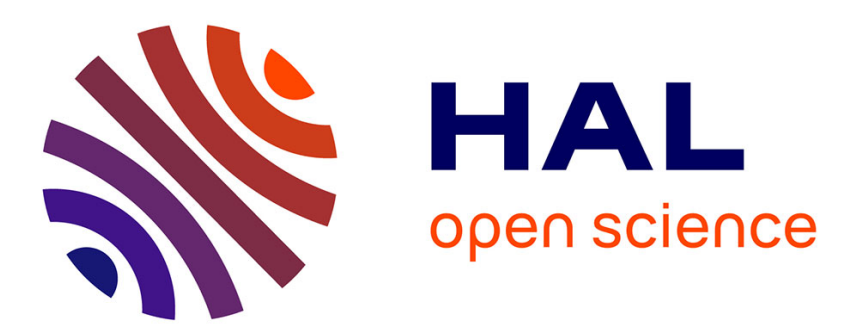

\title{
Biochemical characterization of MI-ENG1, a family 5 endoglucanase secreted by the root-knot nematode Meloidogyne incognita
}

Christel Béra Maillet, Laury Arthaud, Pierre Abad, Marie-Noelle Rosso

\section{To cite this version:}

Christel Béra Maillet, Laury Arthaud, Pierre Abad, Marie-Noelle Rosso. Biochemical characterization of MI-ENG1, a family 5 endoglucanase secreted by the root-knot nematode Meloidogyne incognita. European Journal of Biochemistry, 2000, 267 (11), pp.3255-3263. 10.1046/j.1432-1327.2000.01356.x . hal-02698949

\section{HAL Id: hal-02698949 \\ https://hal.inrae.fr/hal-02698949}

Submitted on 1 Jun 2020

HAL is a multi-disciplinary open access archive for the deposit and dissemination of scientific research documents, whether they are published or not. The documents may come from teaching and research institutions in France or abroad, or from public or private research centers.
L'archive ouverte pluridisciplinaire HAL, est destinée au dépôt et à la diffusion de documents scientifiques de niveau recherche, publiés ou non, émanant des établissements d'enseignement et de recherche français ou étrangers, des laboratoires publics ou privés. 


\title{
Biochemical characterization of MI-ENG1, a family 5 endoglucanase secreted by the root-knot nematode Meloidogyne incognita
}

\author{
Christel Béra-Maillet, Laury Arthaud, Pierre Abad and Marie-Noëlle Rosso
}

INRA. Unité Santé Végétale et Environnement. Antibes, France

\begin{abstract}
A $\beta$-1,4-endoglucanase named MI-ENG1, homologous to the family 5 glycoside hydrolases, was previously isolated from the plant parasitic root-knot nematode Meloidogyne incognita. We describe here the detection of the enzyme in the nematode homogenate and secretion and its complete biochemical characterization. This study is the first comparison of the enzymatic properties of an animal glycoside hydrolase with plant and microbial enzymes. MI-ENG1 shares many enzymatic properties with known endoglucanases from plants, free-living or rumen-associated microorganisms and phytopathogens. In spite of the presence of a cellulose-binding domain at the C-terminus, the ability of MI-ENG1 to bind cellulose could not be demonstrated, whatever the experimental conditions used. The biochemical characterization of the enzyme is a first step towards the understanding of the molecular events taking place during the plant-nematode interaction.
\end{abstract}

Keywords: cellulase; cellulose binding; endoglucanase; plant parasitism; root-knot nematode.

Natural plant cellulose is a polysaccharide composed of $\beta$-Dglucopyranosyl units joined by 1,4-glycosidic bonds. It is a carbon and energy source for a large number of cellulolytic free-living and rumen symbiotic microorganisms, which have developed a large panel of plant cell-wall degrading enzymes [1-3]. Moreover, the plant cell wall is a major mechanical barrier to the propagation and development of plant pathogens, many of which also produce cellulolytic and pectinolytic enzymes able to disrupt cell-wall polymers. The root-knot nematode, genus Meloidogyne, is an endoparasite that has evolved very tight interactions with its plant host. The success of parasitism depends for a large part on the capacity of the infective larva to penetrate the root tip and to migrate intercellularly towards the vascular cylinder.

Cellulolytic enzymes from microorganisms have been studied extensively in terms of structure and enzymatic properties. Cellulases catalyse the hydrolysis of $\beta$-1,4-glycosidic bonds. They are divided into endoglucanases that cleave the glucan chains at interior sites and cellobiohydrolases that release cellobiose from the chain ends. Microorganisms have developed two main strategies to degrade cellulose. Aerobic fungi and bacteria secrete batteries of individual but synergistically acting enzymes, while anaerobic microorganisms associated with the rumen of chewing animals utilize highly structured multienzyme complexes (cellulosomes) operating at the cell surface. Most cellulases secreted by aerobic organisms

Correspondence to M. N. Rosso, Unité Santé Végétale et Environnement, 123 Bd. F. Meilland, 06600 Antibes, France. Fax: + 33 493678955,

Tel.: + 33 493678942, E-mail: rosso@antibes.inra.fr

Abbreviations: CBD, cellulose-binding domain; Cip, cellulosome integrating protein from Clostridium spp.; CM-cellulose, carboxymethylcellulose; CM-cellulase, carboxymethylcellulase; MUC, 4-methylumbelliferyl $\beta$-D-cellobioside; MUG, 4-methylumbelliferyl $\beta$-D-glucoside; $\mathrm{NaP}_{\mathrm{i}}$, sodium phosphate buffer.

Enzymes: endoglucanase (EC 3.2.1.4.)

Note: web site availble at http://www.inra.fr

(Received 26 January 2000, accepted 29 March 2000) have a characteristic modular structure composed of a catalytic domain linked to a functionally independant cellulose-binding domain (CBD) by a flexible linker peptide [4]. In plants, most cellulases lack the ancillary CBD domain. Cellulase catalytic domains have been classified according to sequence-based homologies into 12 of the 77 glycoside hydrolase families [5] (http://afmb.cnrs-mrs.fr/ pedro/CAZY/ghf.html). Similarly, CBDs have been classified into 13 families according to similarities in primary structure [6].

Only a few cellulases have been purified from animals. Cellulase activities have been detected in molluscs [7,8] and snails [9], but whether cellulase is produced by the animal itself or an associated microorganism is difficult to establish until isolation of the corresponding gene. Endogenous production of cellulase by animals has only recently been demonstrated for plant parasitic nematodes $[10,11]$ and termites [12]. In termites, two family $9 \beta$-1,4-endoglucanase cDNAs have been cloned consisting of a single catalytic domain [13]. Concerning cyst nematodes, two categories of family $5 \beta$-1,4-endoglucanase genes have been cloned in each of the two genera analysed, one with and one without CBD [10]. The first glycoside hydrolase gene, named $M I-E N G 1$, isolated from the root-knot nematode Meloidogyne spp. encodes a $\beta$-1,4-endoglucanase composed of a catalytic domain and a CBD joined by a linker rich in proline and hydroxyamino-acid residues [11]. The MI-ENG1 catalytic domain belongs to the family 5 of glycoside hydrolases, which is the largest cellulase family. The MI-ENG1 CBD belongs to family II, which so far has been composed of bacterial hydrolase CBDs.

Here we present the biochemical characterization of MI-ENG1. The enzymatic properties of MI-ENG1 are described in terms of physico-chemical properties, mode of action, substrate specificity and cellulose binding ability. This work presents the first complete biochemical characterization of an animal family 5 glycoside hydrolase, and allows the comparison of its enzymatic properties with those of enzymes from microbe and plant origin. The role of this enzyme in nematode parasitism is discussed. 


\section{MATERIALS AND METHODS}

\section{Nematode cultures, bacterial strains, plasmids and growth conditions}

Meloidogyne incognita nematodes were cultured on greenhouse-grown tomato plants and collected as described previously [11]. Caenorhabditis elegans nematodes were multiplied in vitro on Escherichia coli OP50 [14].

$E$. coli $\mathrm{DH} 5 \alpha$ was used as the recipient strain for recombinant plasmids. E. coli cells were grown on Luria-Bertani medium [15]. Transformed bacteria were grown on LuriaBertani medium supplemented with $100 \mu \mathrm{g} \cdot \mathrm{mL}^{-1}$ ampicillin and $1 \mathrm{~mm}$ isopropyl thio- $\beta$-D-galactoside. The plasmid pENG1, containing the MI-ENG1 coding sequence, was isolated from a pcDNA II (Invitrogen) cDNA library from $M$. incognita J2 [11]. A plasmid containing a fusion of the CelA3 catalytic domain with the CipC CBD isolated from Clostridium cellulolyticum [16], called CelA-CipC, was kindly provided by Chantal Tardif (Bioénergétique et Ingénierie des Protéines, CNRS, IBSM-IFR1, Marseille, France). This vector was used as a positive control in substrate binding assays.

\section{Preparation of protein extracts}

Nematode homogenate was obtained by grinding frozen $M$. incognita preparasitic $\mathrm{J} 2 \mathrm{~s}$ or $C$. elegans in $50 \mathrm{~mm}$ sodium phosphate buffer $\left(\mathrm{NaP}_{\mathrm{i}}\right)$. Juvenile stylet secretions were collected as described previously [11].

$E$. coli cells in the late logarithmic phase were harvested by centrifugation at $8000 \mathrm{~g}$ for $15 \mathrm{~min}$. Cells expressing MI-ENG1 were resuspended in $50 \mathrm{~mm} \mathrm{NaP}, \mathrm{pH}$ 5.0. Cells expressing the CelA-CipC fusion protein were resuspended in $50 \mathrm{~mm} \mathrm{NaP}$, $\mathrm{pH}$ 7.0. The bacteria were disrupted by sonication at $4{ }^{\circ} \mathrm{C}$ (four treatments of $20 \mathrm{~s}$ each, separated by $30 \mathrm{~s}$ on ice). After centrifugating the total extracts at $10000 \mathrm{~g}$ for $20 \mathrm{~min}$, the protein soluble extracts were used for enzyme activity characterization. Protein concentrations were determined by the Bradford procedure [17].

\section{Enzyme assays}

Endoglucanase activity was assayed by measuring the decrease in viscosity of a carboxymethylcellulose (CM-cellulose) solution. Protein extracts were incubated in $50 \mathrm{~mm} \mathrm{NaP}$, $0.3 \% \mathrm{CM}$-cellulose at a given temperature. After incubation, the reaction was stopped by boiling for $20 \mathrm{~min}$, then the sample was left to cool down to room temperature. The time required for the passage of the solution between two points marked on a $2-\mathrm{mL}$ bulb pipette was measured. The reduction in viscosity was measured by comparing the time of passage of the incubated sample with that of a nonincubated one. To evaluate the effect of $\mathrm{pH}$ on activity, enzymatic assays were conducted in $50 \mathrm{~mm} \mathrm{NaP}$ ranging in $\mathrm{pH}$ from 4.5 to 8.0.

The substrates barley $\beta$-glucan, laminarin, lichenan, oat spelt xylan, medium viscosity CM-cellulose and Sigmacell 101 were obtained from Sigma and the microcrystalline cellulose Avicel PH-101 from Fluka. Tomato cell walls were extracted from tomato leaves following the procedure described by Keller $\mathrm{et}$ al. [18]. Each substrate $(1 \%)$ was incubated for $2 \mathrm{~h}$ at $50{ }^{\circ} \mathrm{C}$ with the protein extracts in the presence of $2 \mathrm{~mm}$ phenylmethanesulfonyl fluoride in order to inhibit proteolysis. Released sugars were quantified by the ferricyanide method [19]. 4-Methylumbelliferyl $\beta$-D-glucoside (MUG) and 4-methylumbelliferyl
$\beta$-D-cellobioside (MUC) $\left(1 \mathrm{mg} \cdot \mathrm{mL}^{-1}\right)$ (Sigma) were used on agar plates to detect exoglucanase or cellobiase activity under UV light.

\section{Thin-layer chromatography}

Samples $(10 \mu \mathrm{L})$ and standards (glucose and cellobiose $1 \mathrm{~mm}$ each) were spotted on thin-layer silica gel plates (CCM 60F254, Merck KGaA). Sugars were separated in one dimension as previously described [20] except that the separating mixture was butanol/acetic acid/water $(8: 10: 1.5)$.

\section{Binding assays}

The recombinant MI-ENG1 (and positive control CelA-CipC) were tested for binding to cellulose by incubating soluble protein extracts in a $1 \%$ Sigmacell $101,1 \%$ microcrystalline PH-101 cellulose (Fluka), $50 \mathrm{~mm} \mathrm{NaP}$ pH 5.0 solution (or $\mathrm{pH} 7.0$ in the case of CelA-CipC), for $120 \mathrm{~min}$ at $50{ }^{\circ} \mathrm{C}$ and at room temperature. Samples were collected after 0, 10, 30, 60 and $120 \mathrm{~min}$ incubation and then centrifuged $5 \mathrm{~min}$ at $10000 \mathrm{~g}$. Supernatants were assayed for CM-cellulase activity. Negative controls without substrate were used to measure possible $E$. coli extract proteolysis during the incubation and to calculate the percentage of substrate-binding enzymes in the experimental samples.

Binding of MI-ENG1 to plant cells was assayed as described by Ding et al. [21], except that $2 \mathrm{~mL}$ of soluble protein extract $\left(2 \mathrm{mg} \cdot \mathrm{mL}^{-1}\right)$ were added to a $15-\mathrm{mL}$ of fresh tobacco (Nicotiana tabacum) cell suspension culture. The culture was gently agitated for $36 \mathrm{~h}$. Tobacco cells were fixed in $3 \%$ paraformaldehyde/ $\mathrm{NaCl} / \mathrm{P}_{\mathrm{i}} \quad\left(32.9 \mathrm{mM} \quad \mathrm{Na}_{2} \mathrm{HPO}_{4}, \quad 1.77 \mathrm{~mm}\right.$ $\mathrm{NaH}_{2} \mathrm{PO}_{4}, 0.14 \mathrm{M} \mathrm{NaCl}, \mathrm{pH} 7.4$ ) for $16 \mathrm{~h}$ at $4{ }^{\circ} \mathrm{C}$, then $4 \mathrm{~h}$ at room temperature, washed twice in $\mathrm{NaCl} / \mathrm{P}_{\mathrm{i}}$ and blocked in $3 \%$ $\mathrm{BSA} / \mathrm{NaCl} / \mathrm{P}_{\mathrm{i}}$ for $15 \mathrm{~min}$. The cells were incubated with a $1: 250$ dilution of mouse polyclonal anti-(MI-ENG1-MBP fusion) $\mathrm{Ig}$ (where $\mathrm{MBP}$ is maltose-binding protein) in $1 \%$ $\mathrm{BSA} / \mathrm{NaCl} / \mathrm{P}_{\mathrm{i}}$, followed by a $1: 100$ dilution of anti-(mouse IgG) FITC-conjugated Ig in $1 \% \mathrm{BSA} / \mathrm{NaCl} / \mathrm{P}_{\mathrm{i}}$. Each incubation step was followed by three 20 -min washes in $\mathrm{NaCl} / \mathrm{P}_{\mathrm{i}}$.

\section{SDS/PAGE and zymogram}

PAGE was performed as described by Laemmli [22] with a Mini Protean II Dual Slab cell electrophoresis apparatus (Bio-Rad Laboratories). Proteins in the gels were stained by Coomassie blue. For the CM-cellulase zymogram, PAGE was run under nondenaturing conditions except that SDS was added to the running buffer and $0.1 \% \mathrm{CM}$-cellulose was added into the polyacrylamide gel. CM-cellulase activity was visualized in gels with $0,1 \%$ Congo red, after three washes in $1 \mathrm{M} \mathrm{NaCl}$ to remove SDS and $15 \mathrm{~h}$ incubation at $37{ }^{\circ} \mathrm{C}$ in $50 \mathrm{~mm} \mathrm{NaP}$, $\mathrm{pH} 5.0$.

\section{Antibody production}

A truncated inactive form of MI-ENG1 fused to the MBP was obtained by digestion of pENG1 with EcoRI and BamHI then ligation of the digested fragment in frame with the MBP in the pMAL-p2 expression vector (New England Biolabs Inc.). The resulting recombinant protein was lacking the first 137 amino acids from MI-ENG1. The MI-ENG1-MBP protein was expressed in E. coli and purified on an amylose column (New England Biolabs Inc.) according to the supplier's instructions. Mouse polyclonal antibodies directed to MI-ENG1-MBP were 
produced by Eurogentec. The activity and specificity of the serum obtained were checked by ELISA. ELISA tests showed that the anti-(MI-ENG1-MBP) serum cross-reacted with the CelA-CipC fusion protein with an affinity slightly lower than for MI-ENG1-MBP. This cross-reaction could be explained by the presence of common epitopes in the two family 5 endoglucanase catalytic domains.

\section{Western blotting}

Protein samples were loaded on a $13 \%$ SDS-polyacrylamide gel. After electrophoresis the proteins were transferred to a nitrocellulose membrane (Hybond-C, Amersham) by electroblotting. For immunodetection the membranes were incubated with 1: 1000 mouse anti-(MI-ENG1-MBP) polyclonal Ig, followed by a $1: 5000$ diluted peroxidase-conjugated monoclonal goat anti-(mouse IgG) Ig (Jackson ImmunoResearch

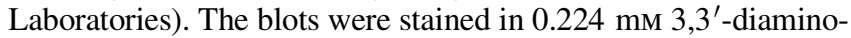
benzidine, tetrahydrochloride in hydrogen peroxide (Pierce). The relative molecular masses of the proteins were estimated with prestained low range molecular mass markers (Bio-Rad).

\section{RES U LT S}

\section{Expression of MI-ENG1 in E. coli and M. incognita}

A full-length cDNA clone previously isolated from M. incognita [11] and encoding a CM-cellulase of 506 amino acids named MI-ENG1 was studied for enzymatic properties.

Soluble extracts of $E$. coli DH5 $\alpha$ cells containing either the empty vector pcDNAII or the pENG1 recombinant plasmid were analysed by zymogram run under nondenaturating conditions. The zymogram revealed after staining a unique band at about $54 \mathrm{kDa}$ in E. coli/pENG1 cell extracts (Fig. 1A), which is consistent with the predicted $53.4-\mathrm{kDa}$ molecular mass of MI-ENG1. The total CM-cellulase activity present in $M$. incognita $\mathrm{J} 2$ homogenate and $\mathrm{J} 2$ stylet protein secretions were also examined on this zymogram. Two major activity bands were detected in the homogenate at about $62 \mathrm{kDa}$ and up to $120 \mathrm{kDa}$, whereas only the $62-\mathrm{kDa}$ band was revealed in the stylet protein secretions. No clear band was detected in either sample around $54 \mathrm{kDa}$. As potential $\mathrm{N}$-glycosylation sites are present on the MI-ENG1 deduced protein sequence [11], and as the linker region that separates the catalytic and the cellulose binding domains is rich in hydroxyaminoacids, we suggest that MI-ENG1 could be glycosylated in the nematode.

MI-ENG1 was detected in nematode homogenate and stylet secretions by Western-blot analysis using a polyclonal antiserum raised against a truncated inactive form of MI-ENG1 linked to a MBP (Fig. 1B). The polyclonal anti-(MI-ENG1MBP) serum reacted strongly with a protein whose molecular mass is $62 \mathrm{kDa}$ in $M$. incognita homogenate (Fig. 1B) and with three other proteins of lower molecular masses (42, 40 and $34 \mathrm{kDa}$ ). The polyclonal serum did not react with $C$. elegans homogenate used as a negative control. Furthermore, no signal was observed on Western-blots treated with an anti-MBP monoclonal antibody, suggesting that the reaction obtained with anti-(MI-ENG1-MBP) Ig was not due to the presence of a MBP in the extracts analysed (not shown). The 62-kDa protein was the only protein recognized in stylet secretions by the anti(MI-ENG1-MBP) serum (Fig. 1B), suggesting that the other proteins detected in the nematode homogenate could be degradation products of MI-ENG1 or nonsecreted cellulases sharing common epitopes with MI-ENG1. No protein was detected at $54 \mathrm{kDa}$ on Western blots, confirming the zymogram result and suggesting that the $62-\mathrm{kDa}$ protein corresponds to the molecular mass of MI-ENG1 after post-translational modification such as glycosylation.

\section{Physico-chemical properties of the endoglucanase}

The endoglucanase activity of MI-ENG1 was tested by viscosimetry. The CM-cellulase activity expressed by E. coli cells producing MI-ENG1 was quantified by measuring the changes in viscosity of a CM-cellulose solution before and after incubation with the cell extracts. We ensured that the measured activity was proportional to the amount of enzyme and the incubation time.

Soluble cell extracts were incubated at $50{ }^{\circ} \mathrm{C}$ in $0.3 \%$ $\mathrm{CM}$-cellulose solutions ranging from $\mathrm{pH} 3.0$ to $\mathrm{pH} 8.5$. For each $\mathrm{pH}$ condition the decrease in viscosity of the CM-cellulose solution was measured. The optimum activity of MI-ENG1 was observed at pH 5.0 (Fig. 2A) and the enzyme retained $80 \%$ of its activity between $\mathrm{pH} 4.5$ and 6.5. There was a sharp decrease of activity below $\mathrm{pH} 4.0$ and a slow gradual decrease at alkaline $\mathrm{pH}$ values.

The extracts were then incubated in $0.3 \%$ CM-cellulose, $\mathrm{pH}$ 5.0, at various temperatures. A maximum of activity was detected at $50{ }^{\circ} \mathrm{C}$ (Fig. 2B), and MI-ENG1 retained about $80 \%$ of its activity between 45 and $60{ }^{\circ} \mathrm{C}$. The enzyme was inactivated above $65^{\circ} \mathrm{C}$, but retained $50 \%$ of activity when incubated between 30 and $50{ }^{\circ} \mathrm{C}$. Therefore the enzyme is active in a large spectrum of temperature conditions, as was observed for $\mathrm{pH}$ conditions.

The effect of the chelating agent EDTA on MI-ENG1 endoglucanase activity was also tested. The enzyme was not inhibited when incubated in 5, 10, 15 or $20 \mathrm{~mm}$ EDTA (not shown), suggesting that MI-ENG1 does not require divalent cations to degrade CM-cellulose. Furthermore, addition of $5 \mathrm{~mm}$ calcium and magnesium in the incubation buffer did not produce any effect on MI-ENG1 activity. This is also the case for the majority of glycoside hydrolases from family 5 , in contrast to family 9 glycoside hydrolases whose activity involves divalent cations [23-25]. Divalent metallic cations

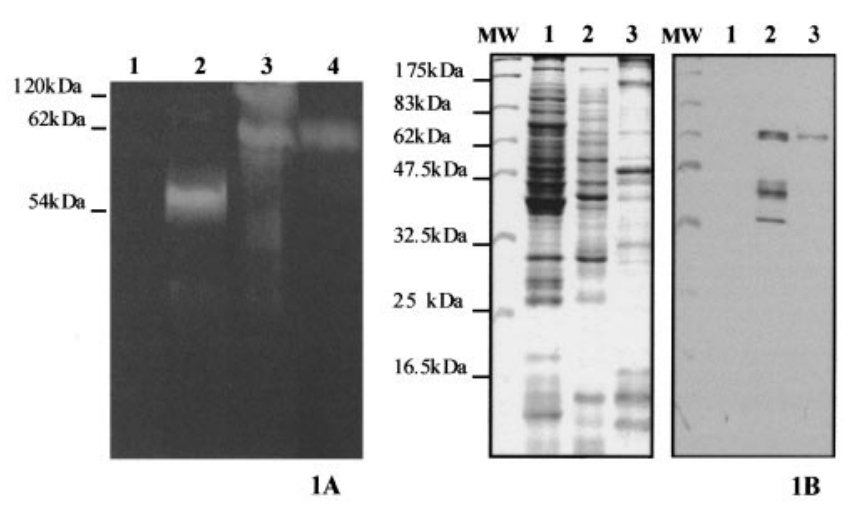

Fig. 1. CM-cellulase activity and MI-ENG1 detection in bacteria, nematode extracts and stylet secretions. (1A) Zymogram analysis of CM-cellulase activity in E. coli control extracts (lane 1), MI-ENG1 E. coli extracts (lane 2), M. incognita J2 total homogenate (lane 3), M. incognita J2 stylet secretions (lane 4). (1B) Detection of MI-ENG1 by Westernblotting in C. elegans total homogenate (lane 1), M. incognita J2 total homogenate (lane 2), M. incognita J2 stylet secretions (lane 3). Left panel, Coomassie blue stained PAGE gel. Right panel, Western-blot. MW, molecular mass markers. 

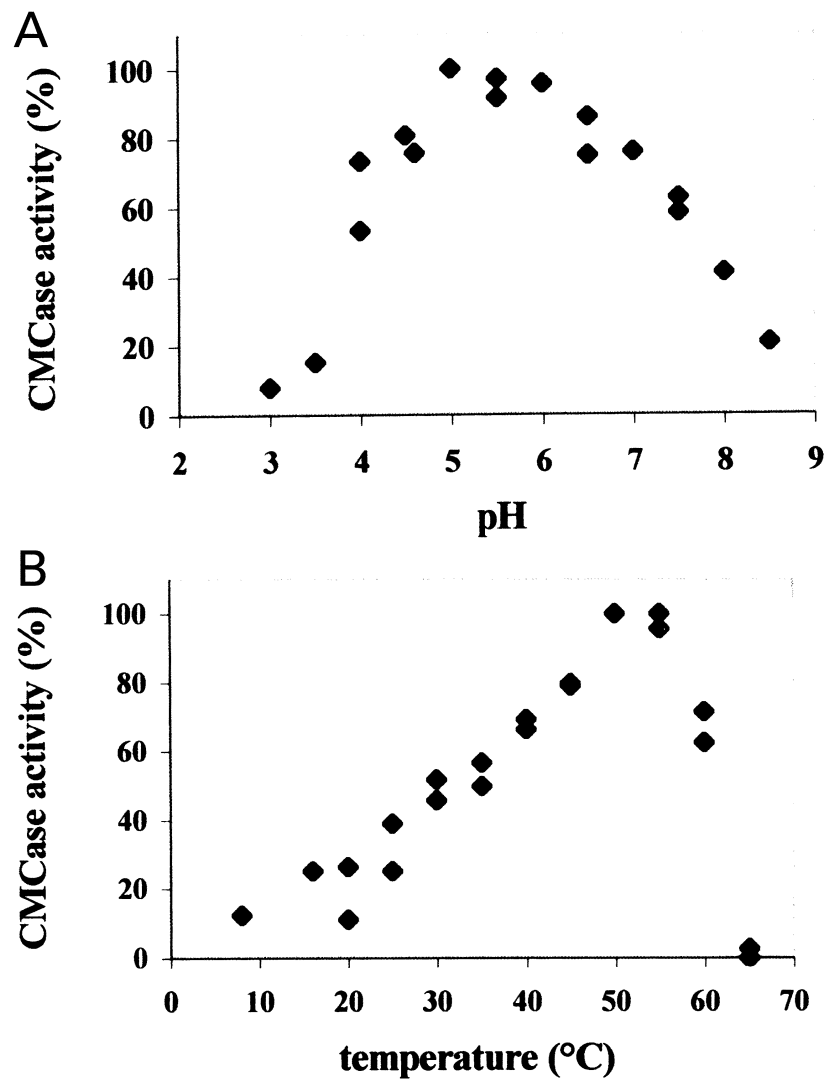

Fig. 2. Effect of $\mathrm{pH}$ and temperature on MI-ENG1 endoglucanase activity. (A) $\mathrm{pH}$ effect on $\mathrm{CM}$-cellulase activity in $\mathrm{NaP}_{\mathrm{i}}$ buffers ranging in $\mathrm{pH}$ from 3.0 to 8.5 , incubation temperature $50{ }^{\circ} \mathrm{C}$. (B) Temperature effect on CM-cellulase activity in $\mathrm{NaP}_{\mathrm{i}}$ buffer $\mathrm{pH}$ 5.0. Relative activity is expressed as percentage of maximum activity. Values obtained in two repetitions of the experiment are shown.

$\left(\mathrm{Fe}^{2+}, \mathrm{Co}^{2+}, \mathrm{Cu}^{2+}, \mathrm{Ni}^{2+}, \mathrm{Zn}^{2+}\right.$ and $\left.\mathrm{Mn}^{2+}\right)$, known to produce inhibitory effects on family 5 glycoside hydrolases, were tested for inhibition of MI-ENG1 activity. For each cation tested, cell extracts were incubated in 1 and $5 \mathrm{~mm}$ ion solutions. MI-ENG1 was inhibited by $\mathrm{Zn}^{2+}$ and $\mathrm{Cu}^{2+}$ cations; its activity decreased, respectively, by 30 and $50 \%$ in the presence of $5 \mathrm{mM} \mathrm{ZnCl}_{2}$ or $\mathrm{CuSO}_{4}$ (not shown). $\mathrm{SO}^{2-}$ and $\mathrm{Cl}^{-}$ions did not affect enzyme activity.

As cellulases of most cellulolytic organisms are known to be sensitive to the presence of simple soluble sugars [4,26,27], we evaluated the effect of several concentrations of glucose and cellobiose on the endoglucanase activity of MI-ENG1. Final concentrations of $25,50,75$ or $100 \mathrm{~mm}$ glucose or cellobiose in the incubation buffer did not inhibit the enzyme activity (not shown), suggesting that MI-ENG1 is not subject to feed-back inhibition by these sugars.

\section{Mode of action and substrate specificity}

Soluble extracts of $E$. coli cells producing MI-ENG1 were incubated for $1 \mathrm{~h}$ in $0.3 \% \mathrm{CM}$-cellulose at $50{ }^{\circ} \mathrm{C}$, and sampled periodically to measure both reduction of viscosity and release of reducing sugars. Figure 3 presents the correlation between the decrease in CM-cellulose viscosity and the reducing sugars produced at the same incubation time. A similar experiment was conducted on total $M$. incognita homogenate in order to compare the mode of action of MI-ENG1 to the total endoglucanase activity produced by the nematode (Fig. 3). For both E. coli and nematode extracts, quite few reducing sugars are liberated for high CM-cellulase activity, according to the endo-acting mode of cellulases. Moreover, the mode of action of MI-ENG1 is quite similar to that of the total endoglucanase activity present in $M$. incognita homogenate, as MI-ENG1 produced only $5 \mu \mathrm{g}$ less reducing sugars than the total homogenate, when retaining $50 \%$ of CM-cellulase activity. No exoglucanase activity could be detected for MI-ENG1 using

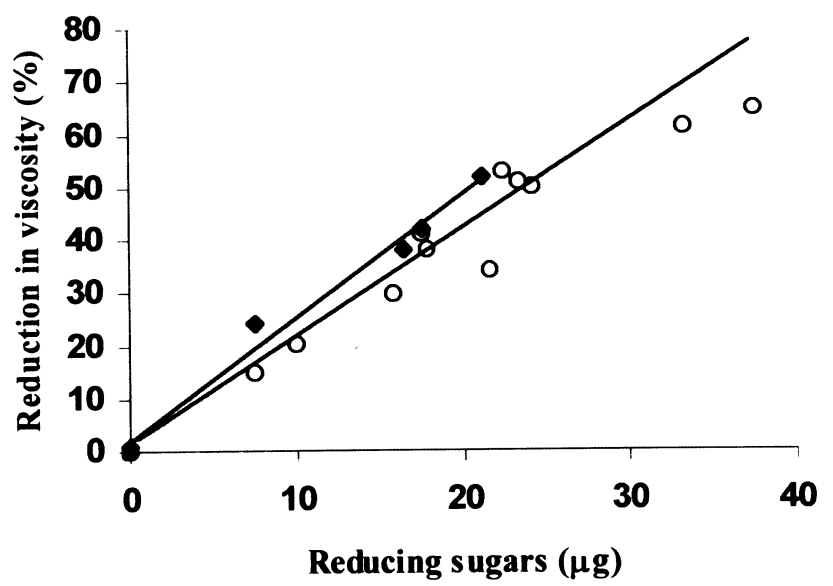

Fig. 3. Correlation between reduction in viscosity and released reducing sugars. $(\diamond)$ MI-ENG1 E. coli cell extracts and (O) M. incognita total homogenate.

Table 1. Substrate specificity of MI-ENG1 endoglucanase. Results are mean values of three determinations. Reducing sugars determined after incubation of cell extracts for $2 \mathrm{~h}$ at $50{ }^{\circ} \mathrm{C}$. One unit (U) of activity corresponds to $\mu \mathrm{g}$ of glucose equivalent for all glycan substrates or xylose equivalent for xylan substrates. Values given correspond to reducing sugars released by $100 \mu \mathrm{g}$ of E. coli/pENG1 extracts. Each substrate was $1 \%$. ND, not detectable. Cell-wall components extracted from fresh tomato cell suspension (see Materials and methods).

\begin{tabular}{lc}
\hline Substrate & Reducing sugars (U) \\
\hline Barley $\beta$-glucan & $190 \pm 14.1$ \\
CM-cellulose & $129 \pm 16.8$ \\
Laminarin & ND \\
Lichenan & $27 \pm 0.7$ \\
Crystalline cellulose (Sigmacell 101) & $3.4 \pm 0.6$ \\
Oat spelt xylan & $2.2 \pm 0.5$ \\
Tomato cellulose & $1.9 \pm 0.5$ \\
Crystalline cellulose (Avicel) & $1.5 \pm 1.2$ \\
\hline
\end{tabular}




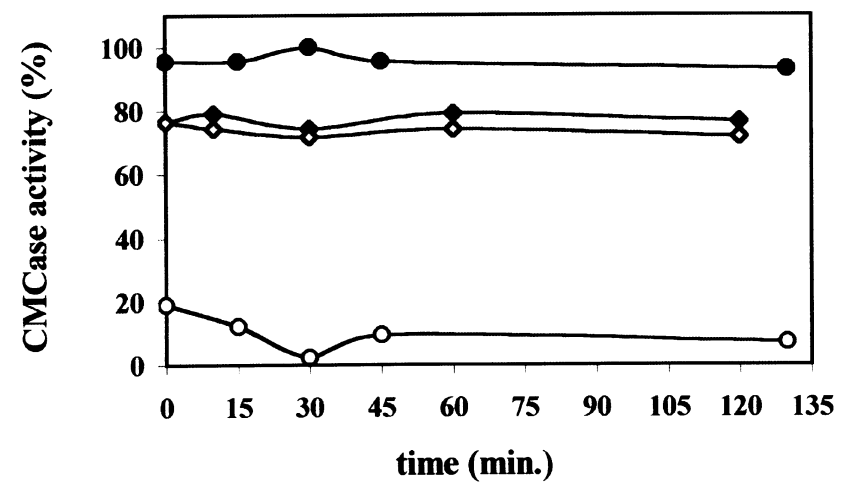

Fig. 4. Cellulose binding assays. Relative CM-cellulase activity measured after incubation of MI-ENG1 $(\diamond)$ and CelA-CipC $(\bigcirc)$ E. coli extracts with crystalline cellulose. For each extract, activity is expressed as percentage of maximum activity relative to the control without substrate $(\bullet$ and $\bullet$ respectively).

MUC as a substrate, nor could cellobiase activity be detected using MUG on agar plates, suggesting that the enzyme is only an endo-acting enzyme.

The products of CM-cellulose hydrolysis by MI-ENG1 were mainly cellobiose and cellotriose as deduced from thin-layer chromatography analysis (not shown).

MI-ENG1 was examined for its ability to hydrolyse carbohydrate polymers containing different types of linkages present in plant cell walls (Table 1). A high activity was detected on barley $\beta$-glucan and CM-cellulose, while no activity could be detected on laminarin ( $\beta-1,3$ linkages), suggesting that MI-ENG1 is unable to cleave $\beta-1,3$ linkages and is exclusively a $\beta-1,4$-endoglucanase. A low activity was detected on lichenan. A difference in organization of $\beta-1,3$ and $\beta-1,4$ linkages in lichenan as compared to $\beta$-glucan could explain this difference in enzyme activity.

Different types of crystalline celluloses as well as cell walls extracted from tomato leaves were tested for MI-ENG1 activity. Activity was barely detectable on Sigmacell or Avicel crystalline celluloses, as well as on tomato cell walls (Table 1), suggesting that the enzyme is not able to degrade plant cell walls by itself. Whereas several family 5 glycoside hydrolases show both cellulase and xylanase catalytic activities [27-30], MI-ENG1 showed no significant activity on xylan.

\section{Cellulose, xylan, tobacco cells binding assays}

The MI-ENG1 deduced protein sequence revealed a modular structure for the enzyme, with a family II CBD at the C-terminus [11]. We checked for the binding capacity of the endoglucanase on different polysaccharidic substrates. Binding to cellulose was first evaluated by incubating MI-ENG1 E. coli extracts in microcrystalline cellulose for $2 \mathrm{~h}$ at room temperature before monitoring CM-cellulase activity in the soluble fraction. As a control for proteolysis of MI-ENG1 during the incubation, cell extracts were incubated for $2 \mathrm{~h}$ in the absence of cellulose and CM-cellulase activity was measured. Figure 4 shows that CM-cellulase activity in the soluble fraction was constant during the incubation time for both the negative control (without cellulose) and the binding assay, suggesting that no proteolysis of the enzyme occurred during the $2 \mathrm{~h}$ of incubation but also that no decrease in activity occurred due to MI-ENG1 binding to the cellulose. The endoglucanase CELA from Clostridium cellulolyticum fused to an additional $\mathrm{CipC} \mathrm{CBD}$ that binds to microcrystalline cellulose [16] was used as a positive control (Fig. 4). Relative CM-cellulase activity immediately decreased from $100 \%$ in the absence of cellulose to $20 \%$ when cellulose was present,

\begin{tabular}{|c|c|c|}
\hline & & $\begin{array}{l}\text { binding } \\
\text { to cellulose }\end{array}$ \\
\hline & 60 & \\
\hline MI-ENG1 & ---------TASVQVP-DKWDNGARFQLVEKNNASTKKCAVKFSLTFASGQQITGIWNV & - \\
\hline $\mathrm{MI}-\mathrm{CBP} 1$ & --------------VILRDKWVNGANCILAFKNNGNARACGVKFELTLGDNQRIQSIWNV & + \\
\hline GR-ENG1 & --------------ーVSTNTWNGGGQVNFEVKNTGSTTLCGVKESVTLPAGTTVAGSWNM & + \\
\hline HG-ENG1 & --------------VPSNTWNGGGQVNEEIKNIGSVPLCGVVFSVSLPSGTTLGGSWNM & ? \\
\hline $\mathrm{TE}-\mathrm{E} 5$ & --AAG----LTATVTKE-SSWDNGYSASVTVRNDTSSTVSQWEVVLTLPGGTTVAQVWNA & + \\
\hline $\mathrm{SH}-\mathrm{Ce} 12$ & SPGAPGEPVTACEVAYATNVWSDGFTADVTVANTGSTPVDSWRLSFTLPSGQRVTNAWNA & + \\
\hline \multirow[t]{3}{*}{$\mathrm{AC}-\mathrm{E} 1$} & -SGAR----CTASYQVN-SDWGNGFTVTVAVTNSGSVATKTWTVSWTFGGNQT ITNSWNA & ? \\
\hline & * * & $\begin{array}{l}\text { binding } \\
\text { to cellulose }\end{array}$ \\
\hline & 120 & \\
\hline MI-ENG1 & QNVTGNSFVLP---DYVTIEAGKQ-YTDAGMNINGPATPPQIKVLGDGK--CVF--- & - \\
\hline $\mathrm{MI}-\mathrm{CBP} 1$ & EKVGDKVYRIP---DYIQLGPGVE--NRDIGVVYNDVPELFHNQGLGQEEGCNIIE- & + \\
\hline GR-ENG1 & NAAGSNEYTLP---SYINIKAKEA--NKDAGMTLNG-SGKPTAKVLSTTA-CSG--- & + \\
\hline HG-ENG1 & ESAGSGQYSLP---SWVRIEAGKS--SKDAGLTFNG-KDKPTAKIVTTKK-C----- & ? \\
\hline TE-E5 & QHTSSGNSHTFTGVSWNSTIPPGG--TASSGFIASG-SGEPTHCT INGAP-CDEGSG & + \\
\hline $\mathrm{SH}-\mathrm{Ce} 12$ & TVSGPTGAVTATGLAHSAQVAAGASQTFGFQGTYSGTFSKPSGFSLNGAR-CA---- & + \\
\hline $\mathrm{AC}-\mathrm{E} 1$ & AVTQNGQSVTARNMSYNNVIQPGQNTTFGFQASYTG-SNAAPTVA------CAASF- & ? \\
\hline
\end{tabular}

Fig. 5. Comparison of the deduced amino-acid sequence of the MI-ENG1 CBD with family II CBDs. Sequence alignement of MI-ENG1 CBD (GenBank accession number AF100549) with CBDs from MI-CBP1from M. incognita (AF049139), and endoglucanases GR-ENG1from Globodera rostochiensis (AF004523), HG-ENG1from Heterodera glycines (AF006052), CelE5 from Thermomonospora fusca (L01577), Cel2 from Streptomyces halstedii (U51222) and E1from Acidothermus cellulolyticus (P54583). Residues conserved in all sequences are marked with asterisks. Tryptophan residues usually conserved in family II CBDs are in bold. 
showing an $80 \%$ loss of activity due to CelA-CipC binding to cellulose.

In order to evaluate a possible temperature effect on MI-ENG1 adhesion, cellulose-binding experiments were conducted at $10{ }^{\circ} \mathrm{C}, 35{ }^{\circ} \mathrm{C}$ and at the optimal activity temperature $50{ }^{\circ} \mathrm{C}$. No binding of MI-ENG1 to cellulose could be observed whatever the temperature tested (not shown).

As it is known that some CBDs are able to bind to xylan or chitin [31-33], oat spelt xylan- and chitin-binding assays were carried out for MI-ENG1. No binding was observed for both polymers. Considering that commercial cellulose and xylan do not precisely mimic the plant cell-wall complexity, we checked the MI-ENG1 binding capacity on fresh tobacco cell suspensions. Fresh whole tobacco cells were incubated with MI-ENG1 E. coli extracts and adhesion was tested by immunofluorescence using the polyclonal antiserum directed against the fusion protein MI-ENG1-MBP. No binding of MI-ENG1 to tobacco cells could be observed (not shown). On the contrary, binding was clearly observed with CelA-CipC E. coli extracts used as a positive control (not shown). These results suggest that the binding of MI-ENG1 to plant material and purified cellulose or xylan is very weak or that the MI-ENG1 endoglucanase is not able to bind to these substrates under the experimental conditions tested.

Because all experimental procedures used to detect MI-ENG1 substrate binding capacity failed, we examined the protein sequence of the MI-ENG1 CBD in order to assess the possibility of an amino-acid exchange that could induce a loss of substrate-binding capacity. MI-ENG1 CBD was compared to protein sequences of several family II CBDs. From the sequence alignement, no amino-acid motif could clearly be identified as potentially responsible for the absence of binding (Fig. 5).

\section{DISCUSSION}

Cellulases have been extensively studied in the case of cellulolytic microorganisms from the soil and rumen of animals. However, the enzymatic properties of plant or phytopathogen cell-wall degrading enzymes have been poorly analysed. This study is the first extended biochemical characterization of a family 5 endoglucanase produced by a phytoparasitic animal. The biochemical characteristics of MI-ENG1 were analysed in order to have a better understanding of its role in parasitism. Moreover, this study allows the comparison of an animal cellulase with microbial cellulases from the same glycoside hydrolase family.

MI-ENG1 shares many enzymatic properties with known endoglucanases from plants, free-living microorganisms and phytopathogens. By analysing the products of enzymatic reaction and by measuring the liberated reducing sugars, we have demonstrated that MI-ENG1 is an endoglucanase devoid of any exoglucanase activity. Furthermore, substrate specificity analysis showed that MI-ENG1 cleaves $\beta-1,4$ linkages but is unable to cleave $\beta-1,3$ linkages.

The predicted molecular mass of MI-ENG1 is $53.4 \mathrm{kDa}$. However, zymogram and Western-blot analysis together suggested that MI-ENG1 is produced as an active endoglucanase with an approximate molecular mass of $62 \mathrm{kDa}$ in total nematode homogenate and stylet secretions. This result suggests that MI-ENG1 undergoes post-translational modifications such as glycosylation when synthesized in the nematode. This hypothesis is supported by the presence of several potential $\mathrm{N}$ - and O-glycosylation sites in the deduced protein sequence of MI-ENG1. Glycosylation of family 5 glycoside hydrolases has been demonstrated in several cases [34,35]. In plant pathogens, it is assumed that such a glycosylation would protect hydrolases from proteolysis [36]. During infestation, plant pathogens secrete cellulases that are subjected to degradation by plant proteases. Protection of cellulases from proteolysis could then play a major role in the success of pathogen development in planta.

MI-ENG1 shares a lot of physico-chemical properties with family 5 endoglucanases characterized. Optimal MI-ENG1 activity was observed at $\mathrm{pH} 5.0,50{ }^{\circ} \mathrm{C}$. Several cellulases from plants [37], fungi [38,39] or bacteria [40,41] show optimal hydrolytic activities between $\mathrm{pH} 4.0$ and $\mathrm{pH}$ 6.0. Similarly, extracellular endoglucanases secreted by the phytopathogenic enterobacteria Erwinia sp. have an optimal activity at $\mathrm{pH} 5.0$ [42], or retain $80 \%$ of activity at $\mathrm{pH} 5.0$ [43]. These $\mathrm{pH}$ conditions for enzymatic activity are in accordance with the pH 5.5 of the plant cell apoplasm. Furthermore, although no thermostabilizing domain could be shown in MI-ENG1, the enzyme is particularly active at high temperatures (up to $60{ }^{\circ} \mathrm{C}$ ). This is also the case for several bacterial $[40,44]$, fungal [39] or phytopathogen hydrolases such as the endoglucanase CELB from E. carotovora whose optimal temperature is $50{ }^{\circ} \mathrm{C}$ [45]. Optimal temperature and $\mathrm{pH}$ conditions revealed that MI-ENG1 is active over a large spectrum of conditions, as it retains $80 \%$ of its activity between $\mathrm{pH} 4.5$ and 6.5 and $50 \%$ of its activity between 30 and $60{ }^{\circ} \mathrm{C}$. This could be related to the fact that root-knot nematodes are wide-spread in tropical and temperate regions. Therefore, they are subjected to various edaphic and climatic conditions and are able to infect more than two hundred plant species. The ability of MI-ENG1 to be active at diverse $\mathrm{pH}$ and temperature conditions could reflect an ability of the enzyme to degrade host plant cellulosic materials in a large variety of environmental conditions.

The inhibitory effect of $\mathrm{Zn}^{2+}$ and $\mathrm{Cu}^{2+}$ metallic cations on MI-ENG1 activity is a common feature of cellulases and xylanases [46-48], including plant cellulases [24,49]. Furthermore, several family 5 glycoside hydrolases, especially from ruminal cellulolytic bacteria, are also inhibited by these cations [47,50]. Enzyme inhibition by metallic cations usually suggests the presence of at least one sulfhydryl group in the active site, usually a cysteine amino acid, whose oxidation by the cations destabilizes the conformational folding of the enzyme [51], or leads to the formation of disulfide bonds at an irregular position of the protein [24]. Five cysteine residues in the catalytic domain of MI-ENG1 could provide potential metallic cation reactive sites causing enzyme inhibition.

The endoglucanase activity of MI-ENG1 is not subjected to feed-back inhibition by soluble sugars such as glucose or cellobiose, suggesting that enzyme regulation could be provided by other polysaccharides or/and that regulation of the enzyme synthesis may exist. Such a regulation has been observed in most cellulolytic organisms [4] and in phytopathogenic organisms [27,52], where cellulase gene expression is regulated by soluble carbon sources which are easily metabolized.

The MI-ENG1 endoglucanase is not significantly active against crystalline cellulose, like all the family 5 glycoside hydrolases yet characterized. Up to now, cellulases able to hydrolyse microcrystalline cellulose have been found in families 9 and 48 of glycoside hydrolases from ruminal cellulolytic microorganisms [53-56] and termites [57]. No plant or biotrophic phytopathogen cellulase is yet known to degrade crystalline cellulose. A large number of cellulases are inactive or poorly active on this substrate when acting separately, but an efficient degradation can be observed when 
glycoside hydrolases act synergistically or when they are associated in multienzymatic complexes [58]. Whereas cellulolytic ruminal microorganisms hydrolyse efficiently the plant biomass to produce energy and a carbon source, it is assumed that root-knot nematodes only need limited hydrolysis of the cell wall in order to separate adjacent cells when migrating intercellularly in the root tissue. Furthermore, one could hypothesize that plant parasitic nematodes do not produce a large hydrolytic multienzyme complex, but rather a more simple and qualitative panel of hydrolytic enzymes [10,59] (M. N. Rosso, L. Arthaud, T. N. Ledger and P. Abad, unpublished results).

One peculiarity of MI-ENG1 as compared to characterized microbial or plant cellulases is its inability to bind to cellulose under the experimental conditions tested, in spite of the presence of a $\mathrm{CBD}$ at the $\mathrm{C}$-terminus. Whether the native MI-ENG1 binding features are different from the enzyme expressed in bacteria still has to be determined. Few data are available concerning the binding ability of CBDs isolated and binding in some cases is weak and depends on very specific physico-chemical conditions (J. T. Pembroke, personal communication). However, inability to bind to cellulose has been reported in the case of a family IIIc CBD [60]. The MI-ENG1 CBD belongs to family II CBDs. Comparing the MI-ENG1 CBD protein sequence to family II CBD sequences gave no explanation for the absence of binding ability on crystalline cellulose. Tryptophan residues have been shown to be involved in cellulose binding [58]. A peculiarity of CBDs isolated so far from nematodes is the presence of only two conserved tryptophan residues instead of three or four residues in subfamilies IIb and IIa, respectively [58]; the ability of such CBDs to bind to cellulose has been demonstrated in the case of the $M$. incognita cellulose binding protein (MI-CBP1) [21], and the cyst nematode endoglucanase GR-ENG1 (G. Smant, personal communication). CBDs of nematode origin carrying two tryptophan residues could then constitute a new subfamily inside the family II. Some CBDs have been shown to play an important role in cellulase activity and thermostability [60,61]. More studies such as CBD deletion or directed mutagenesis will be necessary in order to analyse whether the MI-ENG1 CBD has any effect on enzyme activity and whether residue substitutions restore cellulose binding ability.

To conclude, the enzymatic properties of $M$. incognita MI-ENG1 are in accordance with the environment the nematode faces during plant invasion. MI-ENG1 shares biochemical characteristics with the family 5 glycoside hydrolases characterized so far and with cellulases isolated from pathogens invading plant tissues intercellularly, such as bacteria or biotrophic fungi. The only peculiarity of the enzyme is its inability to bind efficiently to cellulose under the experimental conditions tested, which may reflect a weak binding or an absence of binding in planta. The lack of observed binding to cellulose together with the little effect of MI-ENG1 on crystalline cellulose or natural cell walls, suggest that MI-ENG1 plays a supporting role to other secreted cellulases. The ongoing isolation of new $\beta$-1,4-endoglucanase genes from $M$. incognita indeed suggests that the nematode secretes several cellulases during parasitism, some of them sharing identical molecular masses (M. N. Rosso, L. Arthaud, T. N. Ledger and P. Abad, unpublished results). Similarly, several cellulase genes have recently been cloned from plantparasitic cyst nematodes [59]. The biochemical and molecular characterization of these new cell-wall degrading enzymes should lead to the understanding of their respective role in parasitism and the molecular events leading to nematodespecific plant tissue alterations.

\section{ACK O W LED GEMENTS}

We gratefully acknowledge Chantal Tardif for the agreement to use the plasmid pA25 containing the CelA-CipC construct, S. Conrod for technical assistance and $\mathrm{T}$. N. Ledger for critically reading the manuscript. This work was supported by the EEC Grant $N^{\circ}$ FAIR1-CT95-0905.

\section{REFEREN CES}

1. Coughlan, M.P. (1985) The properties of fungal and bacterial cellulases with comment on their production and application. Biotechnol. Genet. Eng. Rev. 3, 39-109.

2. Wood, T.M. (1985) Aspects of the biochemistry of cellulose degradation. In Cellulose and its Derivatives: Chemistry, Biochemistry, and Applications (Kennedy, J.F., Phillips, G.O., Wedlock, D.J. \& Williams, P.A., eds), pp. 173-188. Ellis Harwood, Chichester Halsted, UK.

3. Coughlan, M.P. \& Ljungdahl, L.G. (1988) Comparative biochemistry of fungal and bacterial cellulolytic enzyme systems. In FEMS Symposium: Biochemistry and Genetics of Cellulose Degradation (Aubert, J.M., Béguin, P. \& Millet, J., eds), pp. 11-30. Academic Press, London.

4. Béguin, P. \& Aubert, J.P. (1994) The biological degradation of cellulose. FEMS Microbiol. Rev. 13, 25-58.

5. Coutinho, P.M. \& Henrissat, B. (1999) The modular structure of cellulases and other carbohydrate-active enzymes: an integrated database approach. In Genetics, Biochemistry and Ecology of Cellulose Degradation (Ohmiya, K., Hayashi, K., Sakka, K., Kobayashi, Y., Karita, S. \& Kimura, T., eds), pp. 15-23. Uni Publishers Co, Tokyo.

6. Tomme, P., Boraston, A., McLean, B., Kormos, J., Creagh, A.L., Sturch, K., Gilkes, N.R., Haynes, C.A., Warren, R.A. \& Kilburn, D.G. (1998) Characterization and affinity applications of cellulose-binding domains. J. Chromatogr. B. Biomed. Sci. App. 715, 283-296.

7. Marshall, J.J. \& Grand, R.J.A. (1976) Characterization of a beta1,4-glucan hydrolase from the snail, Helix pomatia. Comp. Biochem. Physiol. 53, 231-237.

8. Anzai, H., Nisizawa, K. \& Matsuda, K. (1984) Purification and characterization of a cellulase from Dolabella auricularia. J. Biochem. 96, 1381-1390.

9. Maeda, I., Shimohigashi, Y., Kihara, H. \& Ohno, M. (1996) Purification and characterization of a cellulase from the giant snail Achatina fulica. Biosci. Biotech. Biochem. 60, 122-124.

10. Smant, G., Stokkermans, J.P.W.G., Yan, Y., de Boer, J.M., Baum, T.J., Wang, X., Hussey, R.S., Gommers, F.J., Henrissat, B., Davis, E.L., Helder, J., Schots, A. \& Bakker, J. (1998) Endogenous cellulases in animals: isolation of $\beta$-1,4-endoglucanase genes from two species of plant-parasitic cyst nematodes. Proc. Natl Acad. Sci. USA. 95, 4906-4911.

11. Rosso, M.N., Favery, B., Piotte, C., Arthaud, L., de Boer, J.M., Hussey, R.S., Bakker, J., Baum, T.J. \& Abad, P. (1999) Isolation of a cDNA encoding a beta-1,4-endoglucanase in the root-knot nematode Meloidogyne incognita and expression analysis during plant parasitism. Mol. Plant-Microbe Interact. 12, 585-591.

12. Watanabe, H. \& Noda, H. (1998) A cellulase gene of termite origin. Nature 394, 330-331.

13. Tokuda, G., Lo, N., Watanabe, H., Slaytor, M., Matsumoto, T. \& Noda, H. (1999) Metazoan cellulase genes from termites: intron/ exon structures and sites of expression. Biochim. Biophys. Acta 1447, 146-159.

14. Brenner, S. (1974) The genetics of Caenorhabditis elegans. Genetics 77, 71-94.

15. Sambrook, J.S., Fritsch, E.F. \& Maniatis, T. (1989) Molecular Cloning: a Laboratory Manual, 2nd edn. Cold Spring Harbor Laboratory Press, Cold Spring Harbor, New York.

16. Pagès, S., Gal, L., Bélaïch, A., Gaudin, C., Tardif, C. \& Bélaïch, 
J.P. (1997) Role of scaffolding protein CipC of Clostridium cellulolyticum in cellulose degradation. J. Bacteriol. 179, 2810-2816.

17. Bradford, M.M. (1976) A rapid and sensitive method for the quantification of microgram quantities of protein, utilizing the principle of protein-dye binding. Anal. Biochem. 72, 248-254.

18. Keller, H., Hohlfeld, H., Wray, V., Hahlbrock, K., Scheel, D. \& Strack, D. (1996) Changes in the accumulation of soluble and cell wallbound phenolics in elicitor-treated cell suspension cultures and fungus-infected leaves of Solanum tuberosum. Phytochemistry 42, 389-396.

19. Besle, J.M., Lassalas, B. \& Thivend, P. (1981) Digestion des glucides cytoplasmiques de la féverole par le veau préruminant. Reprod. Nutr. Dev. 21, 629-649.

20. Matheron, C., Delort, A.-M., Gaudet, G. \& Forano, E. (1996) Simultaneous but differential metabolism of glucose and cellobiose in Fibrobacter succinogenes cells, studied by in vivo ${ }^{13} \mathrm{C}-\mathrm{NMR}$. Can. J. Microbiol. 42, 1091-1099.

21. Ding, X., Shields, J., Allen, R. \& Hussey, R.S. (1998) A secretory cellulose binding protein cDNA cloned from the root-knot nematode (Meloidogyne incognita). Mol. Plant-Microbe Interact. 11, 952-959.

22. Laemmli, U.K. (1970) Cleavage of structural proteins during the assembly of the head of bacteriophage T4. Nature 227, 680-685.

23. Chauvaux, S., Souchon, H., Alzari, P., Chariot, P. \& Beguin, P. (1995) Structural and functional analysis of the metal-binding sites of Clostridium thermocellum endoglucanase CelD. J. Biol. Chem. 270, 9757-9762.

24. Ohmiya, Y., Takeda, T., Nakamura, S., Sakai, F. \& Hayashi, T. (1995) Purification and properties of a wall-bound endo-1,4- $\beta$-glucanase from suspension-cultured poplar cells. Plant Cell Physiol. 36, 607-614.

25. Béra-Maillet, C., Broussolle, V., Pristas, P., Girardeau, J.P., Gaudet, G. \& Forano, E. (2000) Characterization of endoglucanases EGB and EGC from Fibrobacter succinogenes. Biochim. Biophys. Acta 1476, 191-202.

26. Hamada, N., Fuse, N., Shimosaka, M., Kodaira, R., Amano, Y., Kanda, T. \& Okazaki, M. (1999) Cloning and characterization of a new exo-cellulase gene, cel3 in Irpex lacteus. FEMS Microbiol. Lett. 172, 231-237.

27. Wang, H. \& Jones, R.W. (1995) A unique endoglucanase-encoding gene cloned from the phytopathogenic fungus Macrophomina phaseolina. Appl. Environ. Microbiol. 61, 2004-2006.

28. Wang, W.Y., Reid, S.J. \& Thomson, J.A. (1993) Transcriptional regulation of an endoglucanase and a cellodextrinase gene in Ruminococcus flavefaciens FD-1. J. Gen. Microbiol. 139, 1219-1226.

29. Vercoe, P.E. \& Gregg, K. (1995) Sequence and transcriptional analysis of an endoglucanase gene from Ruminococcus albus AR67. Anim. Biotechnol. 6, 59-71.

30. Liu, J.H., Selinger, L.B., Hu, Y.J., Moloney, M.M., Cheng, K.J. \& Beauchemin, K.A. (1997) An endoglucanase from the anaerobic fungus Orpinomyces joyonii: characterization of the gene and its product. Can. J. Microbiol. 43, 477-485.

31. Carrard, G. \& Linder, M. (1999) Widely different off rates of two closely related cellulose-binding domains from Trichoderma reesei. Eur. J. Biochem. 262, 637-643.

32. Simpson, H.D. \& Barras, F. (1999) Functional analysis of the carbohydrate-binding domains of Erwinia chrysanthemi Cel5 (Endoglucanase Z) and an Escherichia coli putative chitinase. J. Bacteriol. 181, 4611-4616.

33. Irwin, D., Jung, E.D. \& Wilson, D.B. (1994) Characterization and sequence of a Thermomonospora fusca xylanase. Appl. Environ. Microbiol. 60, 763-770.

34. Saloheimo, M., Lehtovaara, P., Penttila, M., Teeri, T.T., Stahlberg, J., Johansson, G., Pettersson, G., Claeyssens, M., Tomme, P. \& Knowles, J.K. (1988) EGIII, a new endoglucanase from Trichoderma reesei: the characterization of both gene and enzyme. Gene 63, 11-22.

35. Hernandez, L.M., Olivero, I., Alvarado, E. \& Larriba, G. (1992) Oligosaccharide structures of the major exoglucanase secreted by Saccharomyces cerevisiae. Biochem. 31, 9823-9831.
36. Langsford, M.L., Gilkes, N.R., Singh, B., Moser, B., Miller, R.C. Jr, Warren, R.A.J. \& Kilburn, D.G. (1987) Glycosylation of bacterial cellulases prevents proteolytic cleavage between functional domains. FEBS Lett. 225, 163-167.

37. Byrne, H., Christou, N.V., Verma, D.P. \& Maclachlan, G.A. (1975) Purification and characterization of two cellulases from auxin-treated pea epicotyls. Biol. Chem. 250, 1012-1018.

38. Macarron, R., Acebal, C., Castillon, M.P., Dominguez, J.M., de la Mata, I., Pettersson, G., Tomme, P. \& Claeyssens, M. (1993) Mode of action of endoglucanase III from Trichoderma reesei. Biochem. J. 289, 867-873.

39. Monti, R., Terenzi, H.F. \& Jorge, J.A. (1991) Purification and properties of an extracellular xylanase from the thermophilus fungus Humicola grisea var. Thermoidea. Can. J. Microbiol. 37, 675-681.

40. Sheweita, S.A., Ichi-Ishi, A., Park, J.S., Liu, C., Malburg, L.M. Jr \& Doi, R.H. (1996) Characterization of engF, a gene for a noncellulosomal Clostridium cellulovorans endoglucanase. Gene 182, 163-167.

41. Cavicchioli, R. \& Watson, K. (1991) Molecular cloning, expression and characterization of endoglucanase genes from Fibrobacter succinogenes AR1. Appl. Environ. Microbiol. 57, 359-365.

42. El-Helaly, A.F., Abo-e., 1-Dahab, M.K., El-Goorani, M.A. \& Gabr, M.R. (1979) Production of cellulase (Cx) by different species of Erwinia. Zentralbl Bakteriol. 134, 187-192.

43. Park, Y.W., Lim, S.T. \& Yun, H.D. (1998) Cloning and sequencing of the celA gene encoding CMCase of Erwinia carotovora subsp. carotovora LY34. Mol. Cells 8, 27-35.

44. Gong, J., Lo, R.Y.C. \& Forsberg, C.W. (1989) Molecular cloning and expression in Escherichia coli of a cellodextrinase gene from Bacteroides succinogenes S85. Appl. Environ. Microbiol. 55, 132-136.

45. Park, Y.W., Lim, S.T. \& Yun, H.D. (1998) Cloning and characterization of a CMCase gene, celB, of Erwinia carotovora subsp. carotovora LY34 and its comparison to. Cela. Mol. Cells 8, 280-285.

46. Paradis, F.W., Zhu, H., Krell, P.J., Phillips, J.P. \& Forsberg, C.W. (1993) The xynC gene from Fibrobacter succinogenes S85 codes for a xylanase with two similar catalytic domains. J. Bacteriol. 175, 7666-7672.

47. Karita, S., Morioka, K., Kajino, T., Sakka, K., Shimada, S. \& Ohmiya, K. (1993) Cloning and sequencing of a novel endo-1,4-glucanase gene from Ruminococcus albus. J. Ferment. Bioeng. 76, 439-444.

48. Romaniec, M.P., Fauth, U., Kobayashi, T., Huskisson, N.S., Barker, P.J. \& Demain, A.L. (1992) Purification and characterization of a new endoglucanase from Clostridium thermocellum. Biochem. J. 283, 69-73.

49. Wong, Y.S., Fincher, G.B. \& Maclachlan, G.A. (1977) Kinetic properties and substrate specificities of two cellulases from auxintreated pea epicotyls. J. Biol. Chem 252, 1402-1407.

50. Mittendorf, V. \& Thomson, J.A. (1993) Cloning of an endo-(1 $\rightarrow 4)$ -beta-glucanase gene, celA, from the rumen bacterium Clostridium sp. (C. longisporum) and characterization of its product, CelA in Escherichia coli. J. Gen. Microbiol., 139, 3233-3242.

51. Rouvinen, J., Bergfors, T., Teeri, T., Knowles, J.K. \& Jones, T.A. (1990) Three-dimensional structure of cellobiohydrolase II from Trichoderma reesei. Science 249, 380-386.

52. Mäe, A., Heikinheimo, R. \& Palva, E.T. (1995) Structure and regulation of the Erwinia carotovora subspecies carotovora SCC3193 cellulase gene celV1 and the role of cellulase in phytopathogenicity. Mol. Gen. Genet. 247, 17-26.

53. Jauris, S., Rucknagel, K.P., Schwarz, W.H., Kratzsch, P., Bronnenmeier, K. \& Staudenbauer, W.L. (1990) Sequence analysis of the Clostridium stercorarium celZ gene encoding a thermoactive cellulase (Avicelase I): identification of catalytic and cellulosebinding domains. Mol. Gen. Genet. 223, 258-267.

54. Bronnenmeier, K., Kundt, K., Riedel, K., Schwarz, W.H. \& Staudenbauer, W.L. (1997) Structure of the Clostridium stercorarium gene celY encoding the exo-1,4-beta-glucanase Avicelase II. Microbiology 143, 891-898.

55. Reverbel-Leroy, C., Pagès, S., Bélaïch, A., Bélaïch, J.P. \& Tardif, C. 
(1997) The processive endocellulase $c e l F$, a major component of the Clostridium cellulolyticum cellulosome: purification and characterization of the recombinant form. J. Bact. 179, 46-52.

56. Zverlov, V., Mahr, S., Riedel, K. \& Bronnenmeier, K. (1998) Properties and gene structure of a bifunctional cellulolytic enzyme (CelA) from the extreme thermophile Anaerocellum thermophilum with separate glycosyl hydrolase family 9 and 48 catalytic domains. Microbiology 144, 457-465.

57. Watanabe, H., Nakamura, M., Tokuda, G., Yamaoka, I., Scrivener, A.M. \& Noda, H. (1997) Site of secretion and properties of endogenous endo-beta-1,4-glucanase components from Reticulitermes speratus (Kolbe), a Japanese subterranean termite. Insect Biochem. Mol. Biol. 27, 305-313.
58. Tomme, P., Warren, R.A.J. \& Gilkes, N.R. (1995) Cellulose hydrolysis by bacteria and fungi. Adv. Microb. Physiol. 37, 1-81.

59. Yan, Y., Smant, G., Stokkermans, J., Qin, L., Helder, J., Baum, T., Schots, A. \& Davis, E. (1998) Genomic organization of four beta-1,4endoglucanase genes in plant-parasitic cyst nematodes and its evolutionary implications. Gene 220, 61-70.

60. Riedel, K., Ritter, J., Bauer, S. \& Bronnenmeier, K. (1998) The modular cellulase CelZ of the thermophilic Clostridium stercorarium contains a thermostabilizing domain. FEMS Microbiol. Lett. 164, 261-267.

61. Linder, M. \& Teeri, T.T. (1997) The roles and function of cellulosebinding domains. J. Biotechnol. 57, 15-28. 